\title{
Reproductive ecology of the azooxanthellate coral Tubastraea coccinea in the Equatorial Eastern Pacific: Part V. Dendrophylliidae
}

\author{
P. W. Glynn · S. B. Colley $\cdot$ J. L. Maté • J. Cortés \\ H. M. Guzman · R. L. Bailey • J. S. Feingold · \\ I. C. Enochs
}

Published online: 16 February 2008

(C) Springer-Verlag 2008

\section{Erratum to: Mar Biol (2008) 153:529-544 DOI 10.1007/s00227-007-0827-5}

Unfortunately, Fig. 5 contains errors. The "moons" on the bottom of the figure are completely black when they should be represented by half moons. The correct Fig. 5 is given below.

The online version of the original article can be found under doi:10.1007/s00227-007-0827-5.

P. W. Glynn $(\bowtie) \cdot$ I. C. Enochs

Division of Marine Biology and Fisheries,

Rosenstiel School of Marine and Atmospheric Science,

University of Miami, 4600 Rickenbacker Causeway,

Miami, FL 33149, USA

e-mail:pglynn@rsmas.miami.edu

\section{S. B. Colley}

PBS\&J, 3230 West Commercial Boulevard,

Ft Lauderdale, FL 33309, USA

\section{J. L. Maté · H. M. Guzman}

Smithsonian Tropical Research Institute,

Apartado 0843-03092, Panama, Republic of Panama

\section{J. Cortés}

Centro de Investigación en Ciencias del Mar y Limnología,

Universidad de Costa Rica, San Pedro, Costa Rica

R. L. Bailey

6716 Vanessa Drive, Lanham, MD 20706, USA

\section{J. S. Feingold}

Nova Southeastern University Oceanographic Center, 8000 North Ocean Drive, Dania Beach, FL 33004, USA
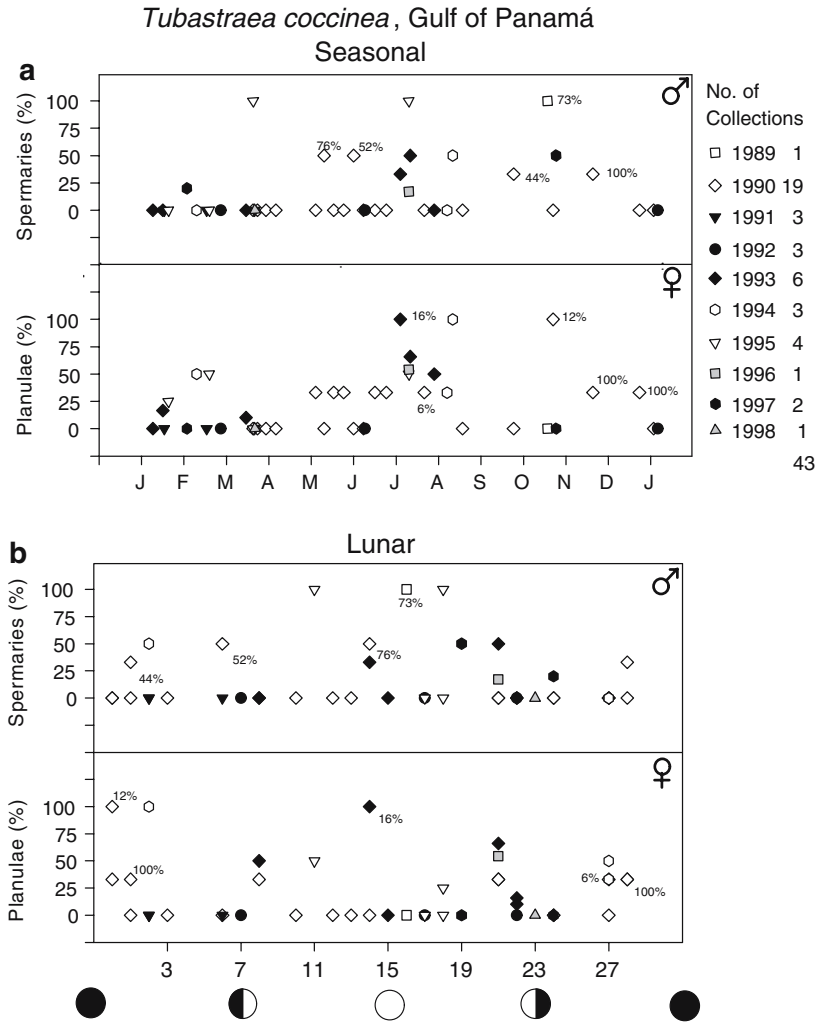

Fig. 5 Tubastraea coccinea. Reproductive activity in the Gulf of Panamá, Panamá as function of season (a) and lunar phase (b), based on combined analyses from 18 collections and 73 colonies examined (1989-1998) at Saboga Island, and from 25 collections and 70 colonies examined (1990-1994) at Taboga Island; further details as in legend to Fig. 4 